\title{
Public clay pot waters: a hidden risk for diarrheal diseases transmission in a cholera endemic area of Cameroon
}

Moussa Djaouda ( $\nabla$ djoubei@gmail.com )

University of Maroua https://orcid.org/0000-0002-8304-8901

Mireille Ebiane Nougang

University of Maroua: Universite de Maroua

Jean Dékouché Ldingté

University of Maroua: Universite de Maroua

Frédérique Demgodéré Thélé

University of Maroua: Universite de Maroua

Roméo Wakayansam Bouba

University of Maroua: Universite de Maroua

Daniel Amani Dawaye

University of Maroua: Universite de Maroua

Serge Hubert Zébazé Togouet

University of Yaounde I: Universite de Yaounde I

Song Liang

University of Florida

Moïse Nola

University of Yaounde I: Universite de Yaounde I

\section{Research Article}

Keywords: Clay pot, Escherichia coli, Maroua, Total coliforms

Posted Date: January 26th, 2022

DOI: https://doi.org/10.21203/rs.3.rs-1277105/v1

License: (c) (1) This work is licensed under a Creative Commons Attribution 4.0 International License.

Read Full License 


\section{Abstract}

Maroua, the capital of Far North Cameroon, is frequently affected by outbreaks of waterborne diseases. Waters stored through public clay pots are common in the city and provided voluntarily by individuals for drinking and ablution. Yet, such service through the clay pots and the stored water lacks management and surveillance. If contaminated, such water may pose infection and transmission risks of waterborne diseases among the population. The water quality of 95 randomly selected public clay pots was assessed through isolation and count of Total Coliforms (TCs) and Escherichia coli. Also analyzed was the bacteriological quality of the water source (borehole or tap) for comparison. For each clay pot, physical characteristics and management information were documented and potential sources of contamination were identified. Results showed that the concentration of TCs ranged from $0 \mathrm{CFU} / 100 \mathrm{~mL}$ in tap water to $160 \mathrm{CFU} / 100 \mathrm{~mL}$ in borehole water. The concentrations of $E$. coli varied from $0 \mathrm{CFU} / 100$ $\mathrm{mL}$ in tap water to $2 \mathrm{CFU} / 100 \mathrm{~mL}$ in borehole water. Depending on the source of water supply and the neighborhood, the concentrations of total coliforms increased significantly in clay pots during water storage in most neighborhoods $(P<0.05)$. Poor management and hygiene were responsible for water contamination.

\section{Introduction}

Waterborne diseases are among the main causes of morbidity and mortality in the world. Such diseases are caused largely by pathogenic microorganisms contained in human or animal feces (WHO 2017). According to the WHO (2016), 1.8 billion people use water contaminated with fecal matters worldwide; such waters may carry a variety of pathogens, causing many diseases, especially dysentery, typhoid, polio, cholera, hepatitis A among others. These diseases are more common in developing countries, due to lack of access to safe drinking water, sanitation and hygiene (WHO 2017).

In the northern part of Cameroon, some studies revealed fecal pollution of groundwater and rivers used for drinking purpose (Wadoubé et al. 2020). Among the biological contaminants responsible for water pollution, enteropathogenic bacteria belonging to the genera Salmonella, Shigella, Escherichia and Vibrio are most commonly found in tropical waters (WHO 2015). These microorganisms come from humans or warm-blooded animals that harbor them in their digestive tracts.

Groundwater is the main source of drinking water in northern Cameroon, where it is collected and treated for distribution to households by the Cameroon Water Utilities company (CAMWATER). However, not all households have access to this water due to the limited coverage of the distribution network, the cost of connection, frequent water cuts and the low purchasing power of the populations. As a result, some households use well water or buy treated water from street vendors for all domestic purposes.

Traditionally, almost all households store water in various types of containers and under various conditions at home for later consumption. For cultural and religious reasons, water clay pots are placed along the streets, typically in front of shops, mosques and in various other public places to allow free access to drinking and ablution water to all people in towns in the northern regions of Cameroon. These 
clay pots are most often supplied with drinking water from public distribution network of CAMWATER and from boreholes. The management of these clay pots is variable and depends on the people who own them.

According to Momba and Notshe (2003) and Wright et al. (2004), the conditions for collecting, transporting and storing water from its source are likely to modify its quality. The risks of degradation of the quality of water stored at home depend first of all on their physicochemical and biological characteristics at their source, then on the evolution of these characteristics during storage and finally on the hygiene within households (Fewtrell et al. 2005; Chalchisa et al. 2017; Khan and AlMadani 2017). The links between the dynamics of bacterial concentrations, and between these concentrations and the chemical characteristics of the stored water also vary with the origin of the water and the storage conditions (Bisi-Johnson et al. 2017). Storing water at home promotes the development of some bacterial species to the detriment of others (Nola et al. 2010; Bisi-Johnson et al. 2017). Studies on the quality of drinking water and the effect of collection, transport, and storage by households, on bacterial loads have been carried out in the city of Maroua (Healy-Profitós et al. 2014; Gorham et al. 2017). However, little attention has so far been paid to the public clay pots and the stored waters. Due to the lack of control of their users, the diversity of their management and their uses, the health risk incurred by consumers of these waters is difficult to predict.

The aim of this study was to determine the bacteriological quality of the water of public clay pots in the city of Maroua and to identify the factors of their contamination. This will help to inform public health advice for improving the water quality of these clay pots and reduce waterborne diseases.

\section{Material And Methods}

\subsection{Study Area}

The city of Maroua is located between $10^{\circ} 31^{\prime}-10^{\circ} 39^{\prime} \mathrm{N}$ and $14^{\circ} 13^{\prime}-14^{\circ} 24^{\prime} \mathrm{E}$, at an average altitude 400 $\mathrm{m}$. The city covers $56 \mathrm{~km}^{2}$ and is divided into 3 semi-autonomous subdivisions, and 25 neighborhoods, with an estimated population of 319,941 (World Population Review 2020). The region has a tropical climate with a long dry season (October to April) and a short rainy season (May to September). Rainfall ranges from 800 to $900 \mathrm{~mm}$ annually with $99 \%$ of annual precipitation falling in the rainy season. The temperature values show wide fluctuations (minimum value around $18^{\circ} \mathrm{C}$ in January and maximum value about $42^{\circ} \mathrm{C}$ in March). There hydrographical network is made up of 'mayos', seasonal (forming in rainy seasons) streams that dry out in dry season.

\subsection{Choice of Sampling Sites}

Due to logistical and time constraints, water samples were not taken from all the public clay pots in the city of Maroua. We have chosen a few sampling sites representative of the study area. A total of 95 clay pots (representing more than 50\%), spreading over 8 neighborhoods, were sampled. A preliminary investigation made it possible to determine the mode of management of these clay pots, their locations, 
and the potential factors of contamination of their waters. A classification was then carried out to group together the clay pots with similar characteristics and a stratified sampling defined the clay pots that were the subject of this study. In addition, public clay pots were not present in all areas of the city. The sampled clay pots were coded using the name initials of the neighborhood followed by a number (e.g. KA1: clay pot number 1 in Kakataré neighborhood, DG2: clay pot number 2 in Dougoï neighborhood, DK5: clay pot number 5 in Djarengol Kodek neighborhood...).

\subsection{Evaluation of the Management Method and the Characteristics of Clay Pots}

A questionnaire was administered to assess the use of clay pot water, management, conditions, and the hygiene and cleanliness of the environment. The questionnaire was written in French and the interview was conducted in French or in Fulfulde, the local language. Key informants were required, after introducing them the objective of the study, to obtain information on management of each selected public clay pot. A pre-survey phase on ten clay pots per investigator randomly chosen was conducted with the aim of evaluating our data collection technique and improving the survey sheet. The survey was conducted on the 95 randomly selected public clay pots.

\subsection{Assessment of the Bacteriological Quality of Clay Pot Waters}

A water sample was taken from each selected clay pot by pouring water directly from the storage container into sterile glass bottle without using a funnel. Another water sample was collected from each clay pot's water source for comparison. The bacteriological analysis focused on the isolation, identification, and count of total coliforms (TCs) and E. coli.

The bacteriological analysis of the water was performed using the membrane filtration technique (American Public Health Association 2012). Water samples in sterile bottle were filtered through a sterile $47 \mathrm{~mm}, 0.45 \mu \mathrm{m}$-pore-diameter, gridded membrane filter, under partial vacuum. The used filters were then removed with sterile forceps and transferred onto m-Endo LES agar plates and incubated at $37^{\circ} \mathrm{C}$ for $18-$ 24 hours for the enumeration of TCs and E. coli. The typical coliform colony on m-Endo has a pink to dark-red colour with a metallic surface sheen. The resulting metallic green sheen colony forming units (CFU) were subsequently identified according to Holt et al. (2000). The identification of each E. coli colony was confirmed using active pharmaceutical ingredient (API) 10S system after a subculture on a standard agar medium.

\subsection{Data analysis}

The characterization of clay pots was made from survey data using multiple correspondence analysis and hierarchical classification. In addition, the most important factors likely to affect the quality of clay pot water were determined using multiple correspondence analysis. The variations in bacterial concentrations of sampled waters as a function of neighborhoods and selected key clay pots characteristics were explored. The comparisons of mean bacterial concentrations according to the 
modalities of each selected factor were carried out using the analysis of variance followed by the Tukey test. The link between qualitative variables from the survey and the bacterial concentrations of clay pot waters was assessed using Kendall rank correlation. All these statistical analyzes were performed using the Rx64 3.6.3 software.

\section{Results}

\subsection{Maroua Public Clay Pot Water Management System}

The survey carried out on public clay pots in the city of Maroua identified the main parameters that characterize them. Table 1 summarize key characteristics and water management of public clay pots based on the survey. The majority of clay pots (63.15\%) had volumes between 20 and $80 \mathrm{~L}$. Aged 0 to 48 months, most of these clay pots $(58.94 \%)$ had lids, were located either at the corner of a street $(22.10 \%)$, or in front of a shop (36.84\%), a mosque (24.21\%) or even in front of homes $(16.85 \%)$. The water contained in these clay pots originated from CAMWATER taps or boreholes. 
Table 1

Characteristics and management of the sampled public clay pots

\begin{tabular}{|lll|}
\hline Parameters & Modalities & Percentage \\
\hline Position de canari & Street & 22.10 \\
& Shop & 36.84 \\
\hline Water suppliers & Mosque & 24.21 \\
& House & 16.85 \\
\hline Frequency of water supply & Children & 12.63 \\
& Women & 10.52 \\
& Men & 43.15 \\
\hline Pot cleaning frequency & Vendors & 33.70 \\
\hline Organisms found in the water & Daily & 90.52 \\
& Thrice a week & 6.46 \\
& Twice a week & 2.00 \\
& Weekly or more & 1.02 \\
\hline & Algae & 80.01 \\
\hline & Insect larvae & 4.21 \\
& Adult insects & 13.68 \\
& Vertebrates & 2.10 \\
\hline & Sand & 49.82 \\
& Suspended solids & 38.24 \\
& Ustensils & 11.93 \\
\hline
\end{tabular}

FW : Filling water without soap ; FWS : Filling water+soap ; RW : Remaining water in clay pot without soap ; RWS : Remaining water in clay pot+soap. 


\begin{tabular}{|lll|}
\hline Parameters & Modalities & Percentage \\
\hline Pot cleaning method & FW & 59.21 \\
& FWS & 6.58 \\
& RW & 8.68 \\
Material used to collect water from clay pot & RWS & 25.52 \\
& Mug & 98.94 \\
Water uses & Calabash & 11.57 \\
& Bowl & 8.40 \\
\hline FW : Filling water without soap ; FWS : Filling water+soap ; RW : Remaining water in clay pot without \\
soap ; RWS : Remaining water in clay pot+soap. & Drinking & 53.89 \\
\hline
\end{tabular}

Children (12.63\%), women (10.52\%), men or vendors (76.83\%) were in charge of supplying these clay pots with water almost every day $(90.52 \%)$; sometimes this was done two to three times a week $(9.48 \%)$. The cleaning frequency of these clay pots depended on the availability of the people responsible for supplying them with water. There are often living organisms (such as deposits of algae, insect larvae, adult insects and even vertebrates) and inert objects (such as children's toys, sand, kitchen utensils and even animal excrement) in these containers' waters. For cleaning of clay pots, people used: remaining water or filling water with or without soap (Table 1). Most people used a mug or a calabash, the condition of which being often dirty, to collect water from the storage container. Figure 1 shows a consumer ready to collect public clay pot water.

Multiple correspondence analysis showed seven key parameters that would distinguish public clay pots each from another: the neighborhood, the source of water supply, the age of the clay pot, the location of the water source, the frequency and material used to clean the clay pot, the persons in charge of supplying the clay pot with water (Figure 2). The factorial representation of the clay pots on a twodimensional plane revealed the structuring of the different variables and showed the grouping of observations according to combinations of variables (Figure 2). The projection of clay pots in a plan of the multiple correspondence analysis showed groups of individuals.

The clay pots PA11, PA10, PA2, PA1, PA15, PA13, PA12 and PA17 are opposed to KA3, KA4 and D012 by the duration of water storage in the clay pot, the cleaning frequency, the source of water supply and the position of the clay pot. Axis 2 allows to see the clay pot DG7, PA18, DG14, PA6, are opposed to MK3, DK14, MK3 and MK7 by variables such as: respecting the hygiene rules, the condition of the container and the water aspect. The hierarchical classification on principal components then brought out three 
groups of clay pots which seem to be associated with the neighborhood where they were found (Figure 2).

\subsection{Bacteriological Quality of Clay Pot Waters}

The total coliform count is used as an indicator of fecal and organic pollution of water. The concentration of TCs ranged from $0 \mathrm{CFU} / 100 \mathrm{~mL}$ in tap water to $160 \mathrm{CFU} / 100 \mathrm{~mL}$ in borehole water (Figure 3). The concentrations of $E$. coli varied from $0 \mathrm{CFU} / 100 \mathrm{~mL}$ in tap water to $2 \mathrm{CFU} / 100 \mathrm{~mL}$ in borehole water. Depending on the source of water supply and the neighborhood, the concentrations of total coliforms increased significantly during water storage in most neighborhoods $(P<0.05)$. The detection of $E$. coli in water samples in very small numbers prevented any meaningful statistical analysis.

The concentrations of coliforms were high in the clay pots of the Palar neighborhood ( $75 \mathrm{CFU} / 100 \mathrm{~mL})$ and low in the clay pots of Kakataré ( $5 \mathrm{UFC} / 100 \mathrm{~mL})$, Djarengol Kodek (3 CFU/100 mL), Doualaré, Makabaye and Bamaré ( $0 \mathrm{CFU} / 100 \mathrm{~mL})$. Regarding E. coli, its maximum concentration was recorded in the clay pots of Kakataré $(3 \mathrm{CFU} / 100 \mathrm{~mL})$ and this bacterium was not detected in the clay pots of the Dougoi, Djarengol kodek, Doualaré, Makabaye, Bamaré and Palar neighborhoods (Figure 3).

The bacteriological quality of clay pot water is presented according to the key factors defined above. Figure 4 shows the variations in the concentrations of TCs and E. coli depending on how the clay pot was cleaned before filling it with water. It shows that the clay pots cleaned with water without disinfectant (soap) were the most contaminated by TCs and E. coli. In areas where bacterial concentrations were high in clay pot water, the containers cleaned with soap showed relatively low bacterial loads $(P<0.05)$.

According to investigations at the study site, individuals who supply clay pots with water play an important role in the water management. Bacterial concentrations varied depending on this parameter. Figure 5 shows that clay pots supplied by women are the least contaminated with TCs and E. coli, unlike those filled by street vendors, men and children, which had higher bacterial load.

TCs were more abundant in clay pots supplied by men in Palar (440CFU/100mL) and less abundant in the clay pots supplied by women in Bamaré $(2 \mathrm{UFC} / 100 \mathrm{~mL})$. The concentration of $E$. coli was higher in the water of clay pots supplied by children in Kakataré (5UFC/100mL) and low in Bamaré (1CFU/100mL). TCs were more abundant in the waters of the Djarengol kodek (420CFU/100mL), more precisely in front of a shop, and less abundant in the clay pot found in front of the mosque in Bamare $(2 \mathrm{CFU} / 100 \mathrm{~mL})$. Bacteriological analysis showed that $E$. coli was more abundant in Dougoï (4 CFU/100mL) more precisely in the clay pot positioned in front of the mosque. It was less abundant in the clay pot waters of Bamaré (OUFC/ $100 \mathrm{~mL})$. Water contamination by $E$. coli was greater in clay pots located in front of the mosque in Djarengol Kodek and less in front of the homes located in Bamaré. The position of the clay pot, although being a determining parameter in the characterization of Maroua clay pots, did not significantly influence the bacterial concentrations of the water. TCs concentrations depending on how often the clay pot was cleaned (daily, once a week, twice a week and three times a week) varied from a neighborhood to another. 
The recorded values showed that the TCs were more abundant in Djarengol Kodek, with a cleaning frequency of twice a week and low in Bamaré regardless of cleaning frequency (Figure 6).

The maximum concentrations of $E$. coli were found in Kakatare $(4 \mathrm{CFU} / 100 \mathrm{~mL})$ with a cleaning frequency of once a week and the minimum in Bamare (Figure 6). The maximum concentrations of TCs were found in the waters of clay pots aged 12 to 24 months in Dougoï $(430 \mathrm{CFU} / 100 \mathrm{~mL})$ and the minimum in the waters of clay pots aged less than 12 months $(0 \mathrm{CFU} / 100 \mathrm{~mL})$. E. coli was more abundant in the waters of clay pots 0 to 12 months old in Kakatare $(5 \mathrm{CFU} / 100 \mathrm{~mL})$ and less abundant in the water of clay pots of all ages in Bamaré.

The frequency of water supply and cleaning of clay pots would explain the variation in TCs concentrations in the sampled clay pot waters $(P<0.05)$ (Tables 2$)$. However, the age of the clay pot was not directly linked to the quality of its water (Table 2). More frequently supplied and cleaned clay pots were less contaminated by TCs than the others. Similarly, as clay pots are cleaned when supplying them with water, the concentrations of TCs increase with the duration of water storage.

Table 2

Kendall correlation between Total Coliforms concentrations, pot age, cleaning and water supply frequency of the clay pots

\begin{tabular}{|llll|}
\hline & $\begin{array}{l}\text { Concentrations of Total } \\
\text { Coliforms }\end{array}$ & $\begin{array}{l}\text { Clay pot cleaning } \\
\text { frequency }\end{array}$ & $\begin{array}{l}\text { Water supply } \\
\text { frequency }\end{array}$ \\
\hline Age & 0.087 & 0.086 & 0.089 \\
\hline $\begin{array}{l}\text { Water supply } \\
\text { frequency }\end{array}$ & $0.206^{*}$ & $0.472^{* *}$ & \\
\hline $\begin{array}{l}\text { Clay pot cleaning } \\
\text { frequency }\end{array}$ & $0.187^{*}$ & & \\
\hline Significance $: * *: P<0.01 ; *: P<0.05$ & & \\
\hline
\end{tabular}

\section{Discussion}

In this study, we examined water safety, measured through bacterial quality of the public clay pots and stored water, and associated factors in Maroua, Far North Cameroon. The main parameters that characterize the public clay pots in Maroua included the neighborhood, the source of water supply, the age of the clay pot, its location (position), the frequency and the material used to clean the clay pot, the category of persons responsible for supplying the clay pot with water. All the other parameters seem to be related to the neighborhood. Indeed, the population settles as a priority in the city's neighborhoods according to very determining factors which may be by affinity, religion or ethnicity. People with the same culture and the same habits tend to deal with clay pots in the same way. The age of the clay pots would be less in the new neighborhoods, since these pots are usually only replaced when damaged. 
The water quality of the public clay pots in Maroua was assessed as well as that of their supply sources (CAMWATER taps or boreholes). According to WHO (2017), no TCs or E. coli should be detected in 100 $\mathrm{mL}$ of drinking water sample. Therefore, water from the boreholes and taps in Maroua is not always of good quality. This study showed that these water sources are often contaminated with TCs. However, $E$. coli was only isolated from borehole water and was absent from tap water during the study. According to Gerba (2009), TCs are more indicative of contamination by organic than fecal matter. In addition, these bacteria can multiply naturally in water. $E$. coli being the best indicator of fecal contamination of water (Edberg et al. 2000), its presence in drinking water indicates that this water has been contaminated by human or animal feces. Although most of the Maroua borehole waters met the standards set by WHO for drinking water, they are often affected by fecal pollution. Several contamination factors have been identified by Gorham et al. (2017). These factors included defecation in nature, the proximity of the water point to latrines or any other sources of pollution, the depth, position and absence of a protective perimeter around the borehole. According to Gwimbi et al. (2019), the poor quality of the water at its abstraction source is a serious public health problem. The absence of $E$. coli in the water of some boreholes and taps confirms the importance of treating the water and protecting it from any source of contamination.

The water clay pots made available to the public in Maroua are most often supplied with water of good microbiological quality. However, this study noted secondary contamination by both TCs and E. coli during water storage. This result corroborates the findings of Healy-Profitós et al. (2014). According to Seib (2011), tap water is usually of good quality; its contamination comes from its use (Momba and Notshe 2003; Wright et al. 2004; Chalchisa et al. 2017; Khan and AlMadani 2017). Dipping a mug, calabash or other kitchen utensil into a clay pot containing water exposes the latter to contamination by bacteria on the hands (Jagals et al. 1999; Duncker 2001; Sobsey 2002; Gundry et al. 2004; Trevett et al. 2005; Rufener et al. 2010). The presence of TCs and E. coli in clay pot water testifies the potential presence of pathogens of fecal origin responsible for diseases such as dysentery, cholera, giardiasis, gastroenteritis, salmonellosis, etc. (WHO 2017). The consumption of water from these clay pots, given their public nature, constitutes a risk for the spread of diarrheal diseases in the city of Maroua. It is essential that their quality be subject to frequent control.

The concentrations of TCs and E. coli in the waters of public clay pots varied depending on the neighborhood. The clay pots of Kakataré presented particularly high concentrations of $E$. coli unlike those of Bamaré where few germs were isolated. The neighborhoods of Maroua are characterized by different modes of water management. The management of stored water affects its microbiological quality. Previous studies have shown that neighborhoods where people respect hygiene measures by using potable water and frequently cleaning water storage containers with water and soap were less susceptible to waterborne diseases (Kumi-kyereme and Amo-adjei 2016; Khan and AlMadani 2017; Thiam et al. 2017). Coliforms were more abundant in the waters of Djarengol Kodek, more precisely in the clay pots positioned in front of a shop. One possible reason for this could be the presence of latrines near this shop (Majorin et al. 2019). The fact that the clay pots are placed on the corner of the street, in front of homes, shops or mosques did not significantly affect the quality of their water. Indeed, the position of the 
clay pot has no direct link with the use of its water. The water is used by all in need regardless of the position of the clay pot. The age of the clay pot has no direct relation to the quality of its water. It is more the maintenance of the clay pot than its age that is important in terms of water quality. The contamination of the water by $E$. coli was also important in the clay pot positioned in front of the mosque in Djarengol Kodek. This would be linked to non-compliance with hygiene rules, the use of water for ablution during daily prayers and use for the toilet. Hand washing after defecation or urination not being done with soap. Compliance with hygiene measures was proved to reduce the incidence of waterborne diseases by improving the quality of drinking water.

Public clay pots supplied with water by women were of better quality than those supplied by men/vendors and children. Women seem to be the most seasoned when it comes to water since they are the ones who do the water chore in the traditional way. Even hygiene awareness campaigns usually target women. Shaheed et al. (2014) have shown that awareness of the health risk incurred by the consumption of poor quality water leads to the awareness of the population on compliance with hygiene measures.

\section{Conclusion}

The tap water was of better quality than that from the borehole. The water of public clay pots originating from these sources was most often contaminated with organic matter and feces. Several risk factors for contamination of the water of public clay pots were identified including the lack of maintenance of the clay pot, non-compliance with hygiene rules by users, storing water for several days and immersing dirty containers in it. The consumption of water from these clay pots, given their public nature, constitutes a risk of the spread of diarrheal diseases in the city of Maroua. It is essential that the quality of their water be subject to frequent control.

\section{Declarations}

\section{Acknowledgements}

The authors would like to acknowledge the participants that granted our interview.

\section{Authors' contributions}

Conceived and designed the study protocol: Moussa Djaouda, Mireille Ebiane Nougang, Moïse Nola; participated in data collection: Frédérique Demgodéré Thélé, Jean Dékouché Ldingté, Roméo Bouba Wakayansam; drafted the paper: Moussa Djaouda, Song Liang; critically revised the manuscript: Serge Hubert Zébazé Togouet, Song Liang, Moïse Nola; interpreted, analyzed data: Moussa Djaouda, Mireille Ebiane Nougang, Jean Dékouché Ldingté, Frédérique Demgodéré Thélé, Daniel Amani Dawaye. All the authors read and approved the submitted version of the manuscript.

\section{Funding}

Page $11 / 18$ 
This work did not receive financial support from anybody or agency.

\section{Data Availability}

Available upon request.

\section{Ethical Responsibilities}

The manuscript complies with all the ethical requirements; it was not submitted to any journal at a time. All the sources and contributors were acknowledged properly.

\section{Consent for publication}

The authors agreed to publish the manuscript.

\section{Conflict of Interest/Competing Interests}

The authors declare that they have no competing interests.

\section{References}

1. American Public Health Association (2012) Standard Methods for the Examination of Water and Wastewater 22nd edn. American Public Health Association/American Water Works Association/Water Environment Federation, Washington, DC, USA

2. Bisi-Johnson MA, Adediran KO, Akinola SA, Popoola EO, Okoh Al (2017) Comparative physicochemical and microbiological qualities of source and stored household waters in some selected communities in Southwestern Nigeria. Sustainability 9:454. https://doi.org/10.3390/su9030454

3. Chalchisa D, Megersa M, Beyene A (2017) Assessment of the quality of drinking water in storage tanks and its implication on the safety of urban water supply in developing countries. Environmental Systems Research 6(12). https://doi.org/10.1186/s40068-017-0089-2

4. Duncker LC (2001) The KAP tool for hygiene. A manual on: knowledge, attitude and practices study for hygiene awareness in the rural areas of South-Africa. Water Research Commission report No TT144/00 Pretoria, South-Africa.

5. Edberg SC, Rice EW, Karlin RJ, Allen MJ (2000) Escherichia coli: the best biological drinking water indicator for public health protection. Symposium series (Society for Applied Microbiology) 88 (29): 106S-116S. https://doi.org/10.1111/j.1365-2672.2000.tb05338.x

6. Fewtrell L, Kaufmann RB, Kay D, Enanoria W, Haller L, Colford JM (2005) Water, sanitation, and hygiene interventions to reduce diarrhoea in less developed countries: a systematic review and metaanalysis. Lancet Infectious Diseases 5(1):42-52. https://doi.org/10.1016/S1473-3099(04)01253-8

7. Gerba CP (2009) Indicator microorganisms. Environmental Microbiology. Academic Press, Inc., New York, pp 485-499 
8. Gorham TJ, Yoo J, Garabed R, Arabi M, Lee J (2017) Water access, sanitation, and hygiene conditions and health outcomes among two settlement types in rural Far North Cameroon. Int $\mathrm{J}$ Environ Res Public Health 14(441). https://doi.org/10.3390/ijerph14040441

9. Gundry S, Wright J, Conroy R (2004) A systematic review of the health outcomes related to household water quality in developing countries. Journal of Water and Health 2(1): 1-13. PMID: 15384725

10. Gwimbi P, George M, Ramphalile M (2019) Bacterial contamination of drinking water sources in rural villages of Mohale basin, Lesotho: exposures through neighbourhood sanitation and hygiene practices. Environ Health Prev Med 24(33). Doi: 10.1186/s12199-019-0790-z

11. Healy-Profitós JM, Arabi M, Lee S, Garabed R, Moritz M, Piperata B, Tien J, Bisesi M, Lee J (2014) Muddying the waters: a new area of concern for drinking water contamination in Cameroon. Int $\mathrm{J}$ Environ Res Public Health 11(12):12454-12472. https://doi.org/10.3390-ijerph111212454

12. Holt JG, Krieg NR, Sneath PHA, Staley JT, Williams ST (2000) Bergey's Manual of determinative bacteriology, 9th edn. Lippincott Williams and Wilkins, Philadelphia

13. Jagals P, Bokato TC, Grabow W (1999) Changing consumer water-use patterns and their effect on microbiological water quality as a result of an engineering intervention. Water SA 25:297-300

14. Khan AM, Al Madani AMAA (2017) Assessment of microbial quality in household water tanks in Dubai, United Arab Emirates. Environ Eng Res 22(1):55-60

15. Kumi-kyereme A, Amo-adjei J (2016) Household wealth, residential status and the incidence of diarrhoea among children under-five years in Ghana. Journal of Epidemiology and Global Health 6(3):131-140. https://doi.org/10.1016/j.jegh.2015.05.001

16. Majorin F, Nagel CL, Torondel B, Routray P, Rout M, Clasen TF (2019) Determinants of disposal of child faeces in latrines in urban slums of Odisha, India, a cross-sectional study. Transaction of the Royal Society of Tropical Medicine and Hygiene 113(5):263-272. https://doi.org/10.1093/trstmh/try142

17. Momba MNB, Notshe TL (2003) The microbiological quality of groundwater-derived drinking water after long storage in household containers in a rural community of South Africa. Journal of Water Supply: Research and Technology 52(1):67-77. 10.2166/aqua.2003.0007

18. Nola M, Djarmaila E, Kemka N, Chihib N-E, Zébazé Togouet SH, Krier F, Servais P, Hornez J-P, Njiné T (2010) Assessment of the future of heterotrophic aerobe bacteria and electrical conductivity in groundwater samples stored in households conditions at different temperatures, in the equatorial region of Central Africa. African Journal of Microbiology Research 4(20):2055-2066

19. Rufener S, Mäusezahl D, Mosler HJ, Weingartner R (2010) Quality of drinking-water at source and point-of-consumption-drinking cup as a high potential recontamination risk: a field study in Bolivia. Journal of Health Population and Nutrition 28(1):34-41

20. Seib MD (2011) Assessing drinking water quality at source and point-of-use: a case study of Koila Bamana, Mali, West Africa. Master Sc. Report, Michigan Technological University 
21. Shaheed A, Orgill J, Ratana C, Montgomery MA, Jeuland MA, Brown J (2014) Water quality risks of « improved » water sources: evidence from Cambodia. Tropical Medecinal and International Health 19(2):186-194. https://doi.org/10.1111/tmi.12229

22. Sobsey MD (2002) Managing water in the home: accelerated health gains from improved water supply. World Health Organization, Geneva, pp 7-70

23. Thiam S, Diène AN, Fuhrimann S, Winkler MS, Sy I, Ndione JA, Schindler C, Vounatsou P, Utzinger J, Faye O, Cissé G (2017) Prevalence of diarrhoea and risk factors among children under five years old in Mbour, Senegal: a cross-sectional study. Infectious Diseases of Poverty 6:1-12. https://doi.org/10.1186/s40249-017-0323-1

24. Trevett AF, Carter RC, Tyrell SF (2005) The importance of domestic water quality management in the context of faecal-oral disease transmission. J Water Health 3:259-270

25. Wadoubé Z, Djaouda M, Maïworé J, Liang S, Nola M (2020) Scarcity of potable water and sanitation facilities in the endemic cholera region of north Cameroon. Journal of Environment Pollution and Human Health 8(1):6-19. DOI: 10.12691/jephh-8-1-2

26. WHO (2015) Cholera, weekly epidemiological record 54610 (40):517-544. https://www.who.int

27. WHO (2016) Cholera, weekly epidemiological record. 6:8https://www.who.int

28. WHO (2017) Guidelines for drinking-water quality fourth edition incorporating the first addendum,Geneva, Switzerland.631. https://www.who.int

29. World Population Review (2020) Cameroon Population 2020 (live) (accessed 18 september 2020) https://worldpopulationreview.com/countries/cameroon.population

30. Wright J, Gundry S, Ronam C (2004) Household drinking water in developing countries: a systematic review of microbiological contamination between source and point of use. Tropical Medicine and International Health 9:106-117

\section{Figures}

\section{Figure 1}

Picture showing a consumer ready to collect public clay pot water.

\section{Figure 2}

Multiple Correspondence Analysis and Hierarchical Classification graphs for data characterizing clay pots in the study area. A) Main distinctive parameters of clay pots; B) Groups of clay pots obtained by hierarchical classification on principal components (the codes represent the clay pots with their neighborhoods). 


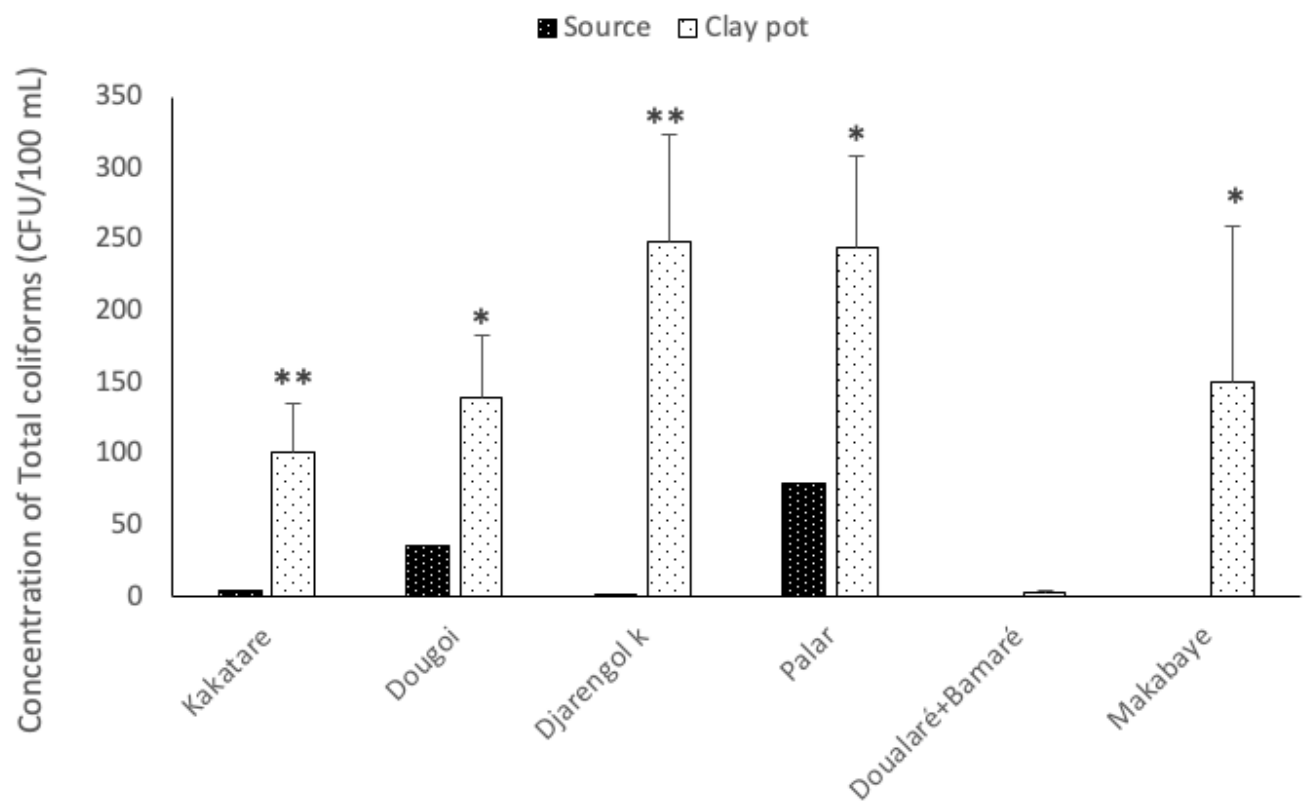

A)

Neighborhood

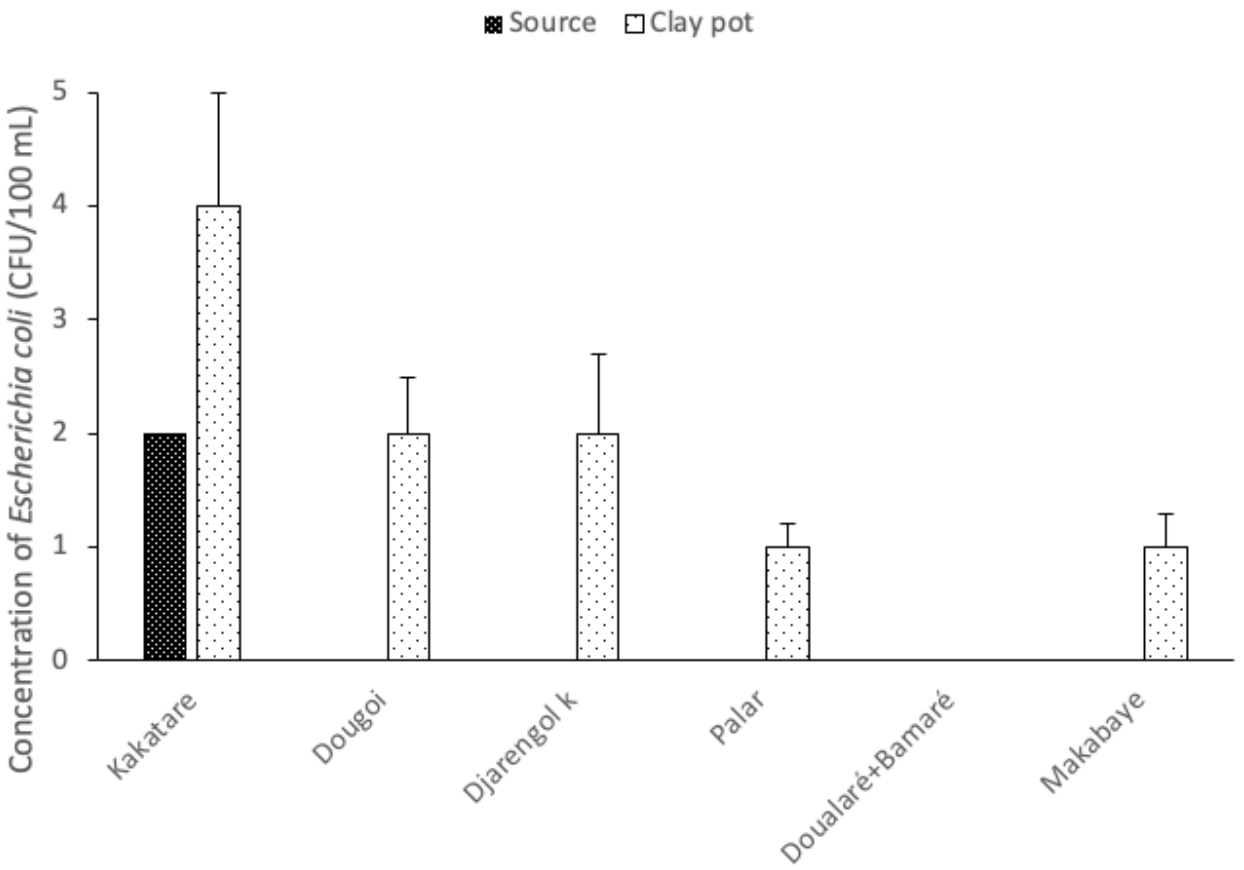

Neighborhood

B)

Figure 3

Variations in the concentrations of Total Coliforms (A) and Escherichia coli (B) in sampled clay pots and their water sources for each neighborhood. 


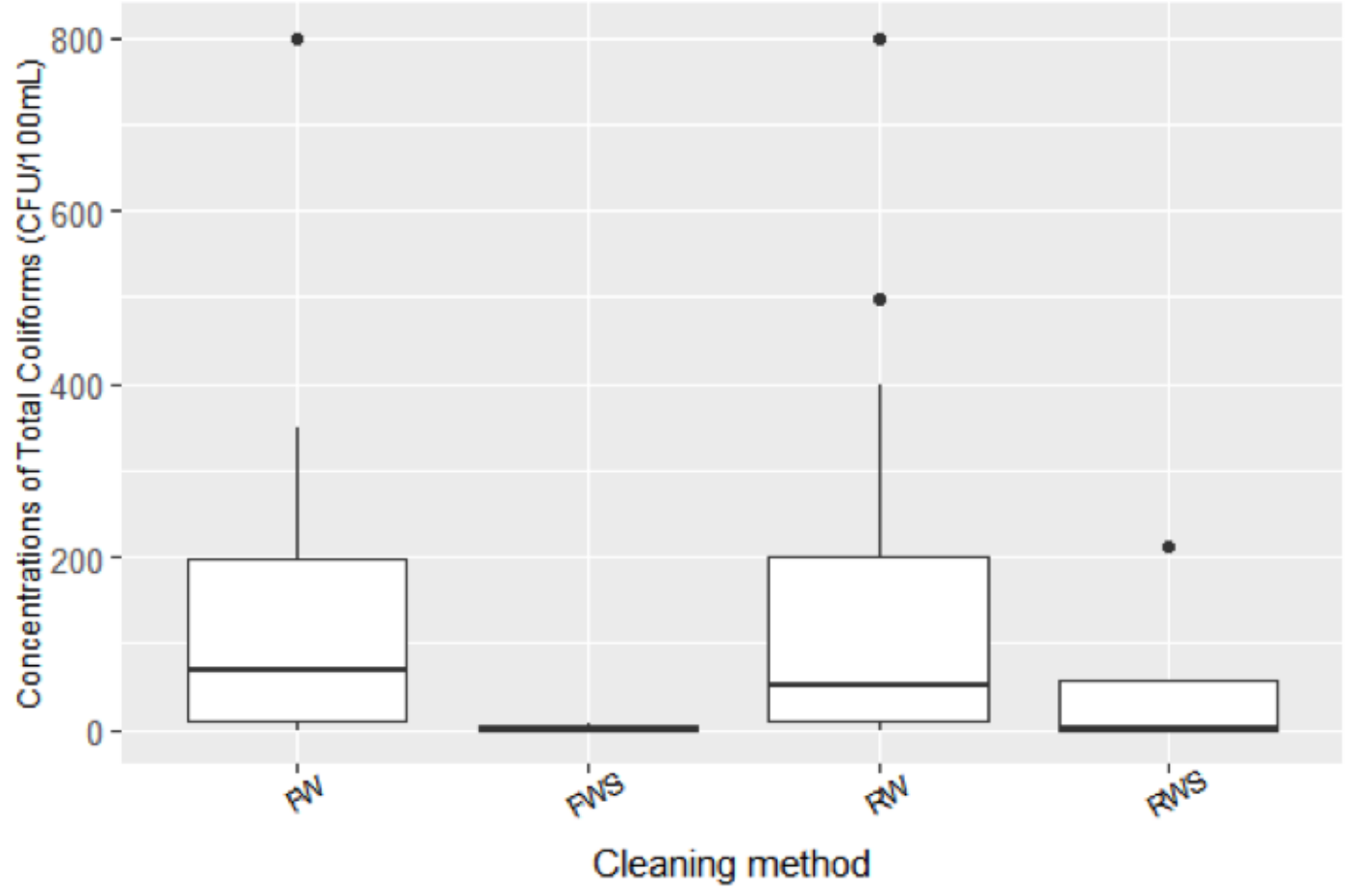

A)

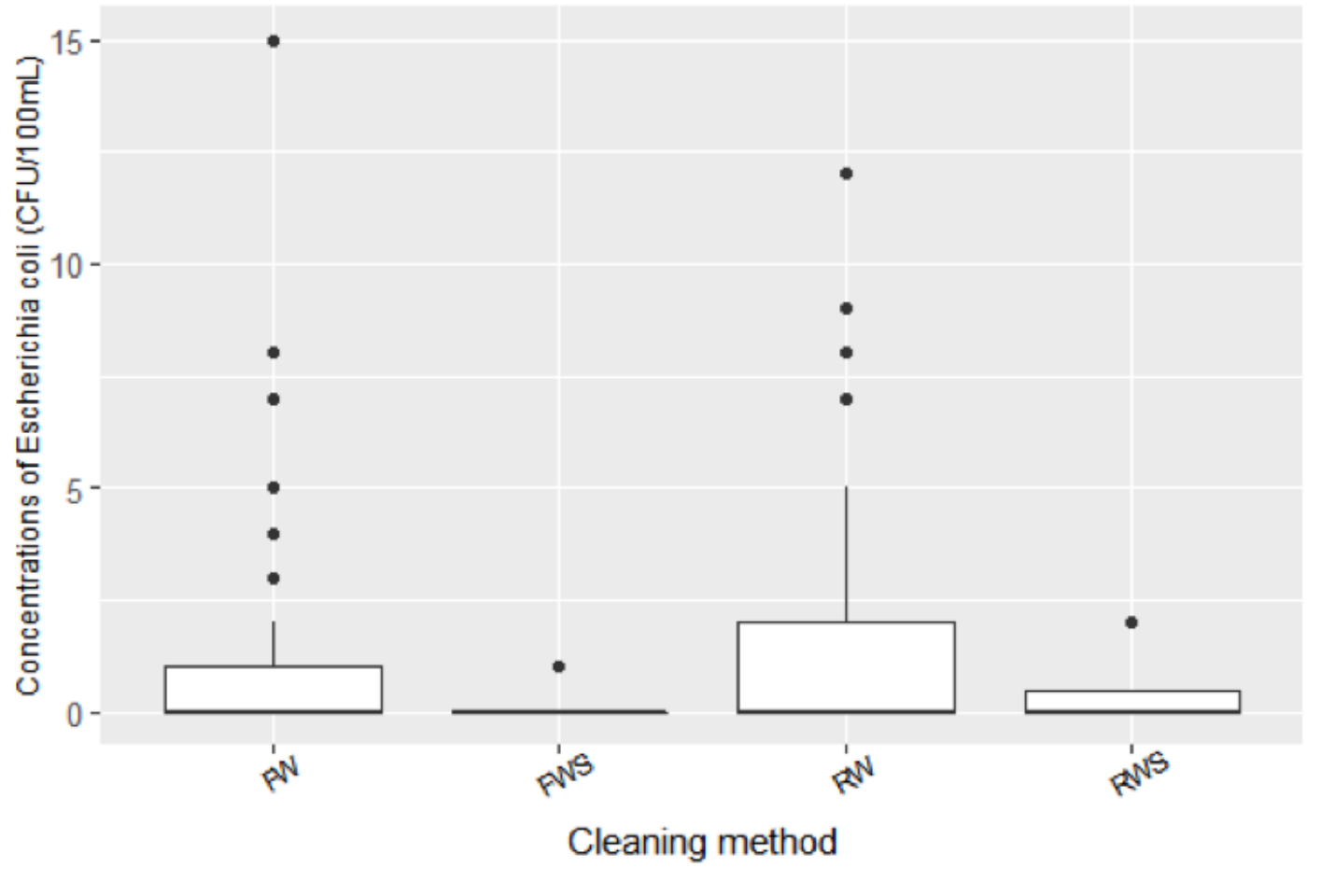

Figure 4

Concentrations of Total Coliforms (A) and Escherichia coli (B) in clay pots according to the method of cleaning in study neighborhoods: FW: with filling water without soap; FWS: with filling water+soap; RW: with remaining water in clay pot without soap; RWS: with remaining water in the clay pot+soap. 


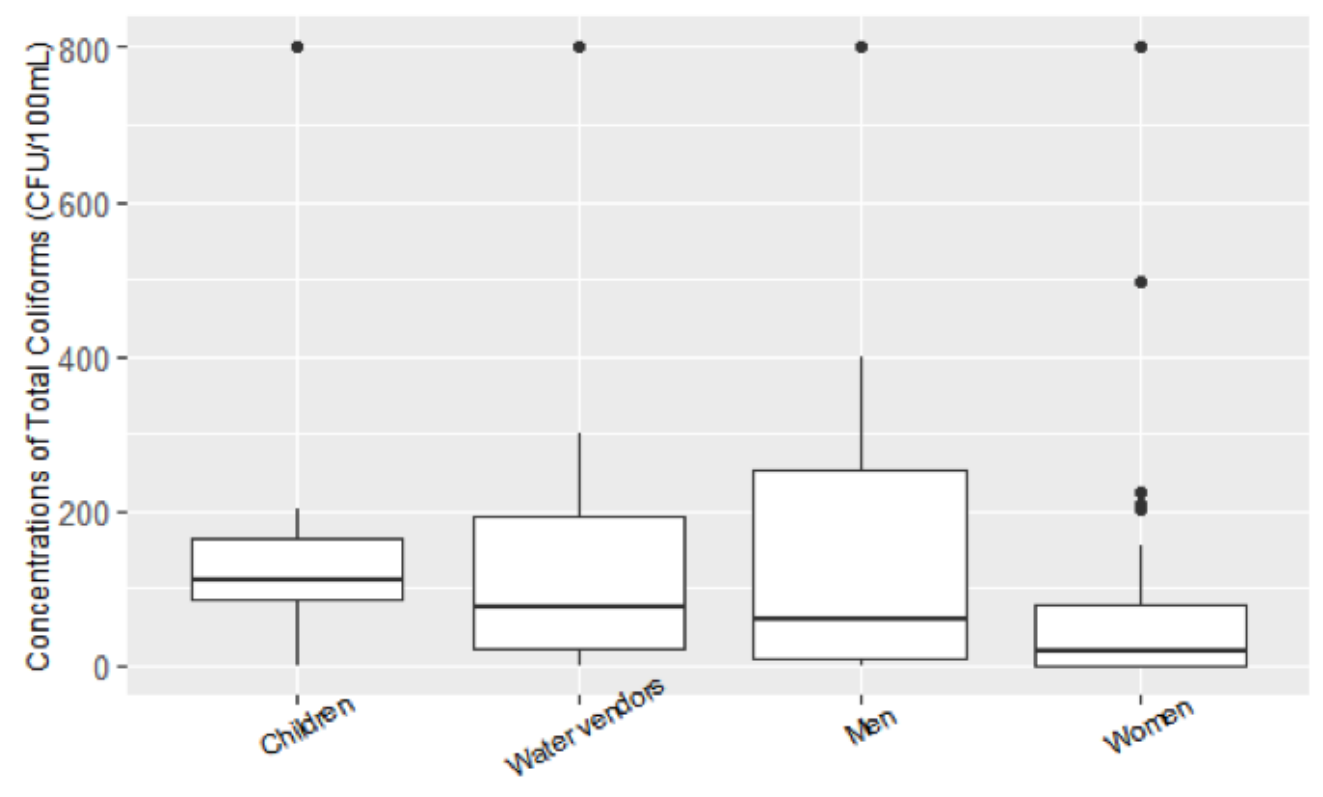

Pot water supplier

A)

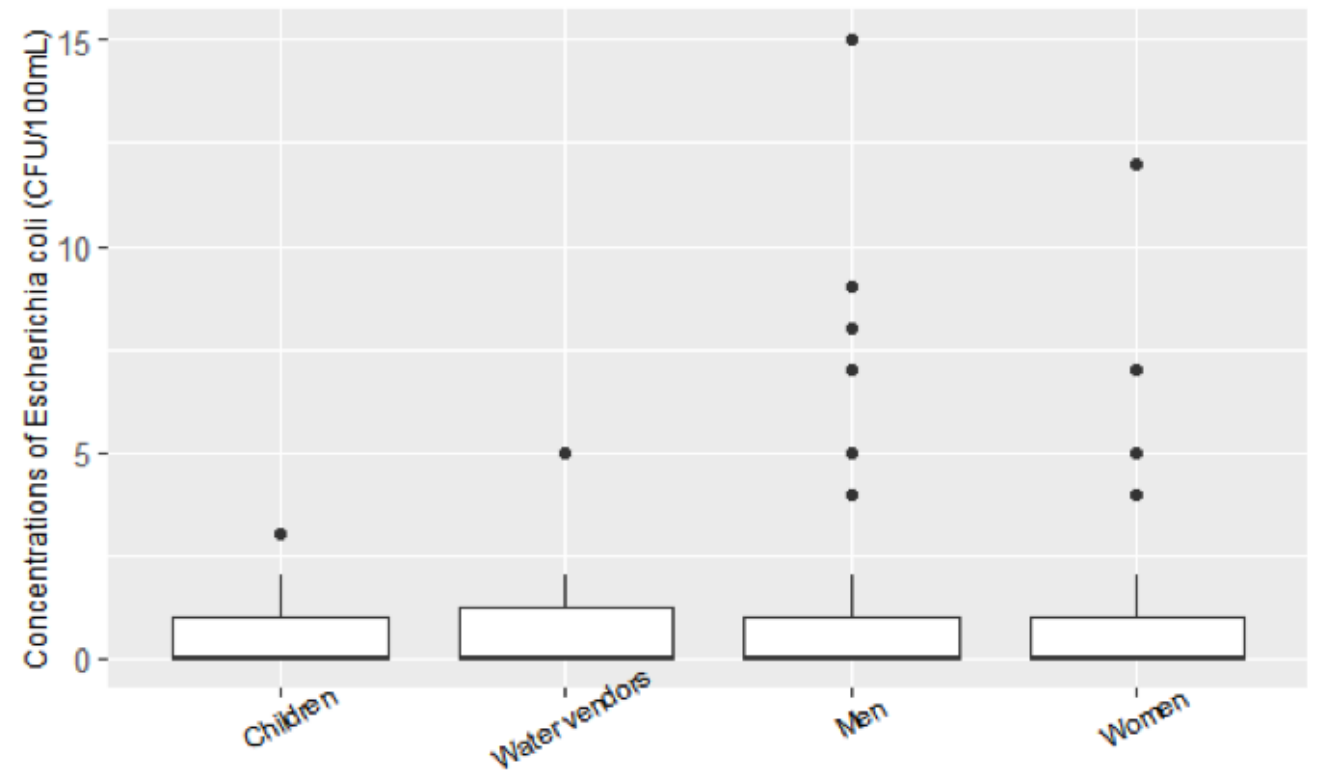

Pot water supplier

B)

Figure 5

Variation in the concentrations of Total Coliforms (A) and E. coli (B) according to the neighborhoods and categories of people who supply the clay pots with water. 
Figure 6

Variation in the abundance of Total Coliforms (A) and E. coli (B) according to the frequency of cleaning of the clay pot.

\section{Supplementary Files}

This is a list of supplementary files associated with this preprint. Click to download.

- Highlights.doc 